\title{
WHAT IS THE IMPACT OF FORECLOSURES ON RETIREMENT SECURITY?
}

\author{
Irena Dushi, Leora Friedberg, and Anthony Webb
}

CRR WP 2010-17

Date Submitted: October 2010

Date Released: November 2010

\author{
Center for Retirement Research at Boston College \\ Hovey House \\ 140 Commonwealth Avenue \\ Chestnut Hill, MA 02467 \\ Tel: 617-552-1762 Fax: 617-552-0191 \\ http://crr.bc.edu
}

Irena Dushi is an economist at the Social Security Administration (SSA), Office of Retirement and Disability Policy, Office of Research, Evaluation and Statistics. Leora Friedberg is an associate professor in the Department of Economics at the University of Virginia (UVa). Anthony Webb is a research economist at the Center for Retirement Research at Boston College. The research reported here was performed pursuant to a grant from SSA funded as part of the Retirement Research Consortium (RRC). The opinions and conclusion expressed are solely those of the author and do not represent the opinions or policy of SSA, any agency of the federal government, the RRC, UVa, or Boston College.

(C) 2010, by Irena Dushi, Leora Friedberg, and Anthony Webb. All rights reserved. Short sections of text, not to exceed two paragraphs, may be quoted without explicit permission provided that full credit, including $\mathbb{C}$ notice, is given to the source. 


\title{
About the Center for Retirement Research
}

The Center for Retirement Research at Boston College, part of a consortium that includes parallel centers at the University of Michigan and the National Bureau of Economic Research, was established in 1998 through a grant from the Social Security Administration. The Center's mission is to produce first-class research and forge a strong link between the academic community and decision makers in the public and private sectors around an issue of critical importance to the nation's future. To achieve this mission, the Center sponsors a wide variety of research projects, transmits new findings to a broad audience, trains new scholars, and broadens access to valuable data sources.

\section{Center for Retirement Research at Boston College}

\author{
Hovey House \\ 140 Commonwealth Avenue \\ Chestnut Hill, MA 02467 \\ phone: 617-552-1762 fax: 617-552-0191 \\ e-mail: crr@bc.edu \\ crr.bc.edu
}

Affiliated Institutions:

The Brookings Institution

Massachusetts Institute of Technology

Syracuse University

Urban Institute 


\begin{abstract}
Using data from several sources, we show that households nearing retirement have lower rates of housing distress than younger households, as measured by arrears and foreclosure rates. However, almost all of the housing wealth gains observed for cohorts aged 51-56 between 1992 and 2004 were erased by 2010, while their mortgages have grown throughout. As a consequence, their loan-to-value ratios are considerably higher, though the percentage paying more than 30 percent of their household income toward their mortgage remains flat. Worrisomely, their financial wealth also declined between 2004 and 2010. Declines in house prices will adversely affect households that need to liquidate housing wealth, and rising mortgage obligations will increase pressure on retirement resources. We develop an econometric model to show factors associated with housing distress and then use the results to forecast housing distress among older households through 2012. We project that the risk of arrears will increase to 3.4 percent in 2010 and 4.4 percent by 2012. We also find that 6.7 percent of HRS households have children or other relatives who are facing housing distress, potentially putting further pressure on their retirement preparedness.
\end{abstract}




\section{Introduction}

The current economic crisis has been unmatched in severity by any since the Great Depression, with employment falling 4.3 percent between 2008 and 2009. ${ }^{1}$ Older households in the 1930s had little in the way of retirement assets, and heavy job losses caused grave economic distress, disproportionately affecting older households and ultimately inducing the passage of the Social Security Act. Today, many households have multiple assets to draw on to smooth consumption in case of job loss or retirement asset losses. Yet, the crash of housing markets, occurring simultaneously with massive job and asset market losses, has undercut the ability of households to ride out the recession, perhaps having disproportionately severe effects on households nearing retirement. $^{2}$

Recessions undermine the ability of households to prepare for retirement; these effects are exacerbated when combined with housing shocks. Some workers may be forced into early retirement by premature job loss, just at a time when many wish to work longer because both their retirement accounts and housing equity have shrunk and, in some cases, their mortgage payments have jumped. Other workers who retain their jobs may take real pay or hours cuts and may have to drain their retirement accounts to meet mortgage payments. As these possibilities suggest, several features cause older households to experience the triple hit of job, asset, and housing market losses differently than prime-age households. Some of these factors have also changed in important ways from earlier recessions.

One factor that has distinguished the experience of older workers in recessions, and that has changed in recent years, involves the nature of their retirement saving. Obviously, older households have accumulated more life-cycle saving than prime-age workers. Although these assets can be used to smooth consumption during recessions, such appropriation simultaneously undermines retirement preparedness. As a result, the form that this saving takes is critical. Over several decades, retiring workers enjoyed increasingly generous annuities deriving from both Social Security and defined benefit (DB) pensions. While these retirement benefits may increase

\footnotetext{
${ }^{1}$ U.S. Bureau of Labor Statistics.

2 According to the Flow of Funds, house values declined 34.6 percent between the fourth quarters of 2006 and 2009, exceeding any drop since at least 1952.
} 
overall wealth and reduce poverty, they come at the cost of reducing liquidity during working years and are unavailable to smooth consumption during recessions. ${ }^{3}$ Recent changes have shifted the retirement saving landscape. Real Social Security benefits flattened out for workers retiring in the 1980s and 1990s and began declining in 2000, and DB pension coverage has dropped, sharply for prime-age workers and more gradually for older workers (Friedberg and Owyang 2002). DB plans have largely been replaced by defined contribution (DC) plans, which have three important features for consideration here. First, they are more liquid than DB plans and thus are available to some extent to smooth consumption during recessions. ${ }^{4}$ Second, and undercutting this, is that they are vulnerable to asset market fluctuations, eroding in the face of the stock market declines of 2007-09. DC plans lost 20 percent of their value between 2007 and 2008, regaining some value the next year but sustaining a two-year loss of 7 percent. $^{5}$ Third, participation in them is often voluntary, raising the risk that people have not saved enough for retirement, although potentially facilitating consumption smoothing during recessions by allowing workers to reduce retirement saving temporarily.

A second factor that may distinguish older workers, and that we focus on in our investigation, is their exposure to the massive housing crisis, which is atypical of post-war recessions. Housing constitutes one of the major forms of wealth of retiring households, yet its illiquidity is well documented; older households rarely reduce housing equity until the death or nursing home entry of one spouse (Venti and Wise 2001). ${ }^{6}$ To this extent, transitory house price declines may have little effect on the retirement preparedness of many older households, given their long horizon over which to ride out fluctuations. Declines in house prices will adversely affect households that need to liquidate housing wealth by drawing down equity or moving perhaps in response to job loss. Also, the increased access to housing credit associated with the post-2000 housing

\footnotetext{
${ }^{3}$ It remains an open question whether public and private pensions raise total retirement wealth. Engelhardt and Gruber (2006) show that Social Security reduced poverty rates, suggesting real wealth increases for at least some.

${ }^{4}$ DC plan assets may be accessed in the event of job exit, with a 10 percent penalty for people under age $591 / 2$. An increasing number of employers allow current workers to borrow against their DC plan balances as well. Notably, DB plans are increasingly offering a lump-sum payout upon job separation as well.

${ }^{5}$ Investment Company Institute, http://www.ici.org/pdf/fm-v19n3.pdf.

${ }^{6}$ Banks et al (2006) find new evidence that older American households downsize in the form of reducing the number of rooms in their residences independent of household demographic changes, by one-tenth of a room between ages 65-69 and 70-74 and again between ages 70-74 and 75-79 and then by about two-tenths of a room between ages 75-79 and ages 80+. They do not further examine whether this downsizing is associated with reduced housing equity.
} 
boom has increased mortgage obligations for many households and exposed them to liquidity problems in meeting housing payments, in response to both rate adjustments on variable-interest loans and income shocks due to job loss. Although older households may be less exposed to such problems, to the extent that they paid off their mortgages and avoided speculating in the housing boom, any increase in mortgage debt will impede their ability to tap housing equity in retirement through, for example, reverse mortgages or downsizing. Little is known about the relative exposure of older households to the housing crisis.

Thus, we investigate the impact of the housing crisis, which differentiates the current recession from previous ones, on the retirement preparedness of older households. To sum up, this impact depends on (1) the extent to which older households liquefied their housing wealth, and (2) the extent to which they then got hit with labor and asset market shocks. The impact of labor market shocks on older workers has been severe, and the impact of asset market shocks is being newly felt, due to the shift from DB to DC pensions. To quantify these effects, we use the Health and Retirement Study (HRS) and the Panel Study of Income Dynamics (PSID), both of which included special housing questions in 2008 and 2009, respectively. We analyze the magnitude of housing distress - mortgage arrears or foreclosure - among households nearing retirement. We then identify socio-economic factors associated with being at risk of arrears and foreclosure. We consider the relative importance of precipitating shocks such as ill health, divorce, and job loss, of high rates of borrowing relative to income and property value, and of local property market conditions. Lastly, we forecast foreclosure rates among older households and calculate the effect of foreclosures on financial preparedness for retirement.

Our analysis results in two main findings. First, we find that households nearing retirement are more exposed to housing market volatility than in the recent past. Their mortgages have risen in value and their participation in the home equity loan market has risen. During the house price boom, their house values rose by more than their mortgages, but since 2004 their mortgages have continued to grow, while their gains in housing wealth in comparison to earlier cohorts has been erased. As a consequence, their loan-to-value ratios are considerably higher, though the percentage paying more than 30 percent of their household income toward their mortgage remains flat. Troublingly, their financial wealth also declined between 2004 and 2010. Our 
second finding is that the incidence of housing distress among older households, while perhaps higher than in the past, is nonetheless relatively low. It was lower for older households in the 2008 HRS, compared to the national average, and had increased in the 2009 PSID but remained lower than among prime-age households in the PSID. ${ }^{7}$ In 2008, 3.0 percent of HRS households with a mortgage were two months or more in arrears on their mortgage payments, and $0.75 \%$ were in foreclosure, compared to national averages of 4.8 percent in arrears and 3.3 percent in foreclosure. ${ }^{8}$ The probit model we estimate reveals that housing distress was significantly affected by layoffs and health shocks, as well as high loan-to-value ratios observed in 2006. Moreover, the incidence of housing distress was greater among black and Hispanic households, even after controlling for income and education, possibly reflecting unfavorable mortgage terms offered to ethnic minorities. We use our econometric model to forecast the risk of mortgage arrears and foreclosures among older households through 2012. We project that the risk of arrears will increase to 4.2 percent in 2010, declining to 3.6 percent by 2012 .

\section{Background}

Households approaching retirement have not experienced a sudden collapse of housing prices of the current magnitude in several decades. Combined with job losses and a tightening of credit, this has led to a spike in foreclosures. Mortgage delinquency and foreclosure rates, as reported by the Mortgage Bankers Association National Delinquency Survey were 7.9 and 3.3 percent, respectively, in the fourth quarter of 2008, up from 5.8 and 2.0 percent in the same quarter of 2007, and 5.0 and 1.2 percent in 2006. The above data shows further substantial increases in delinquencies and foreclosures subsequent to 2008. In contrast, Hurd and Rohwedder (2010), using data from the Internet-based American Life Panel, report somewhat lower delinquency rates, with rates peaking toward the end of 2009.

Historically, home-owners accumulated significant housing equity during their working lives and entered retirement with little or no mortgage debt. In the $1992 \mathrm{HRS}$, the median mortgage

\footnotetext{
${ }^{7}$ We do not know from these data sources how the incidence of housing distress differs for older households currently compared to past cohorts, but we expect that it is worse now, given the trend in loan-to-value ratios. ${ }^{8}$ A potential concern is that households experiencing mortgage arrears might be less likely to be re-interviewed. We found no evidence of a correlation between being re-interviewed and socio-economic characteristics that we identified were associated with experiencing arrears and foreclosure.
} 
among households with a member aged 51-61 was $\$ 15,600$. One might therefore expect the housing crisis to affect older households only to the extent that it reduced the amount of housing wealth available for consumption in retirement or to pass as a bequest, an important issue as the house represents the single most valuable asset of households in retirement, after Social Security. Yet, the AARP Public Policy Institute (2008) finds that those over age 50 represent 28 percent of all households in arrears or foreclosure. Among older households, the highest rates are among traditionally disadvantaged groups. The effects of foreclosure are also arguably more serious for older households who have less time to recover from any resulting financial loss.

The housing crisis has been accompanied by severe job loss and a relatively large correction to the stock market. Older workers are much more exposed to stock market fluctuations than in the past. The reasons are the use of tax incentives to promote retirement saving in the form of Individual Retirement Accounts and 401(k) accounts, and the shift in pension coverage from DB to DC, which shifts financial risk from employers to employees. These factors have led to a substantial increase in stock market participation. Among full-time employees with a pension in the Survey of Consumer Finances, 69 percent had a DB plan and 45 percent had a DC plan in 1983, while 39 percent had a DB plan and 80 percent had a DC plan in 2001 (Friedberg and Owyang 2005). Nevertheless, older workers have higher rates of DB coverage than others, and evidence shows that the wealthiest are the ones who took the biggest hit to their portfolios.

\section{Empirical Strategy}

We employ several approaches in order to analyze housing distress among retiring cohorts. First, we compare cohorts aged 51-56 across different waves of the HRS, focusing on 1992, 1998, and 2004. We examine non-housing retirement assets, housing wealth, and exposure to house price fluctuations. We then follow up on the same cohorts six years later, when they are aged 57-62, adding 2010 data to examine the impact of the housing crisis. Second, we use extra questions on housing asked in the 2008 HRS and the 2009 PSID to analyze socio-economic factors associated with being at risk of arrears and foreclosure. We consider the relative importance of precipitating shocks such as ill health, divorce, and job loss, of high rates of borrowing relative to income and property value, of local property market conditions, and of 
demographic variables such as education and ethnicity. Third, we forecast foreclosure rates among older households, based on their 2006 assets, 2008 levels of housing distress, and predicted rates of job loss and house price changes. Fourth, we analyze reports of respondents about family members of HRS households who have experienced housing distress and the assistance they provided to those family members.

\subsection{The Health and Retirement Study}

The HRS is a detailed longitudinal survey that takes place every two years. It has repeatedly added new cohorts aged 51 and over. It began in 1992 with over 7,600 households that had a member born between 1931-1941 and then added households born between 1942-1947 in 1998 and households born between 1948-1953 in 2004. ${ }^{9}$ Thus, as of 2004, the sample was once again representative of all Americans aged 51 and over, with an oversample of minority and Florida households.

We use the HRS in two ways. First, we analyze household assets and debts across different cohorts entering the HRS. We focus on households aged 51-56 in 1992, 1998, and 2004 and again six years later, when they are aged 57-62. We further extrapolate to households aged 5762 in 2010, based on house price changes in Metropolitan Statistical Areas between 2008 and 2010. Financial respondents were asked detailed questions about different types of assets and debt. Non-response rates are known to be high in survey questions about wealth; when HRS respondents refused to answer questions about exact asset balances, for example, they were invited to provide ranges in which their asset balances fell. The HRS used hot-deck imputation, taking exact information from a respondent who answered the question and had similar characteristics as a respondent who refused. We use these imputed values as part of our analysis. Also, we use sample weights in our analysis to make the samples nationally representative.

\footnotetext{
${ }^{9}$ Older cohorts were also included in 1992 and 1998, but we do not analyze them as our focus is on preparedness for retirement, not the impact of shocks during retirements. Where possible, we make use of the RAND HRS data file, a cleaned version of the original.
} 
Second, we focus on a series of questions asked in the 2008 wave about housing distress. ${ }^{10}$ These questions were asked of anyone with a mortgage in 2008 or anyone who ceased being a homeowner between 2006 and 2008. Of the 17,217 respondents in 11,897 households in the 2008 HRS, respondents in 2,870 households were asked whether they had fallen into arrears on their mortgage or believed they were at risk of falling into arrears, were facing possible foreclosure, had gone through foreclosure, or had lost their home as a result of foreclosure.

A sample of HRS respondents participated in an Internet survey in 2009, the survey instrument containing many questions relating to housing distress. Our analysis of this data reveals that respondents are disproportionately of high socio-economic status. They also have much lower than average levels of housing distress, reflecting both their socio-economic status and the likelihood that loss of one's home likely also results in the loss of one's Internet connection. Although the data has the advantage of being more up to date, we decided not to subject it to further analysis.

\subsection{The Panel Study of Income Dynamics}

The PSID began in 1968 as a longitudinal study of 4,800 families, consisting of a nationally representative sample and a low-income subsample. The offshoots of these families have been added to the survey, growing to more than 7,000 families in 2001. Families were interviewed every year until 1997 and then every two years.

As in the HRS, additional questions to gauge housing distress were asked in 2009. We use these questions, along with information from some of the previous waves, to compare levels of and characteristics associated with housing distress for HRS households with both older and primeage households in the PSID. To facilitate this comparison, we divide the PSID sample into households whose head was born in or before 1953, and so generally comparable to the age cohorts covered in the HRS from 2004 on, and households whose head was born in or after 1954.

\footnotetext{
${ }^{10}$ Almost 50 percent of respondents were surveyed between March and May 2008, and almost 45 percent more were surveyed between June and October.
} 


\section{Comparisons of Housing Wealth Across HRS Cohorts}

We begin by analyzing household assets and debts across different cohorts entering the HRS. We focus on households aged 51-56 in 1992, 1998, and 2004, and the same households aged 5762 six years later (along with those aged 57-62 in 1992 for the sake of comparison). ${ }^{11}$ We focus on both housing and non-housing wealth, as housing wealth is relatively illiquid and therefore unavailable to support consumption during retirement.

Table 1 shows that housing wealth of cohorts aged 51-56 rose between 1992 and 2004, with housing values rising and mortgages also rising but by less. The house value gains were concentrated in the later period, while debt increased throughout but more so later on. The increase in debt did not, interestingly, involve a jump in the percentage of homeowners with a mortgage, so it was entirely on the intensive margin of mortgage size among existing mortgage holders. The median value of the primary residence rose from \$140,400 in 1992 and \$144,000 in 1998 to $\$ 203,000$ in 2004. Meanwhile, the median value of mortgages for the entire sample rose from \$15,600 in 1992 to \$28,800 in 1998 to \$46,400 in 2004 and for mortgage holders rose from $\$ 45,240$ in 1992 to $\$ 69,120$ in 1998 and $\$ 90,480$ in 2004 . The percentage of the sample with a mortgage was 63 percent in 1992 and 66 percent in 2004, though the percentage with a home equity loan rose from 15 percent in 1992 and 1998 to 21 percent in 2004. As a consequence of these changes, home equity rose from a median of \$93,600 in 1992 and 1998 to \$116,000 in 2004, while the mean loan balance rose steadily from 26 percent of home value in 1992 to 30 percent in 1998 and 32 percent in 2004. As another measure of exposure to housing fluctuations, the percentage of households with a mortgage that spent over 30 percent of their household income on mortgage payments went from 7 percent in 1992 to 9 percent in 2004.

At the same time, non-housing financial wealth exhibited small changes at the median, while retirement account balances (DC plans and IRAs) rose. Median net financial wealth (not including housing or business wealth or retirement accounts) stayed almost the same over time, in the range of $\$ 12,000-\$ 17,000$ throughout. Median retirement account balances rose from

\footnotetext{
11 The composition of the sample changes slightly over time due to attrition and the inclusion of new participants in
} the panel. 
$\$ 15,600$ in 1992 to $\$ 26,400$ in 1998 and $\$ 34,800$ in 2004, possibly reflecting a combination of asset market gains and increases in contributions.

Table 2 shows statistics for the same households six years later, when they were aged 57-62. We project housing and financial wealth from 2008 (the latest available HRS data) to 2010, assuming that households experienced the average change in house prices for their Metropolitan Statistical Area (MSA) and stock and bond returns equaling the returns on the S\&P 500 and long-dated corporate bonds. The trends in housing values and mortgages diverged sharply between 2004 and 2010. The median housing value, which increased from \$144,000 in 1998 to $\$ 175,160$ in 2004, then dropped to $\$ 153,360$ in 2010 - erasing much of the gain from the

previous six years. Meanwhile, mortgages continued to grow, with the median among mortgage holders hitting \$69,600 in 2004 and $\$ 87,567$ in 2010. This contributed to a drop in home equity and a sharp jump in the loan-to-value ratio, which had been rising more gradually until 2004. The mean loan-to-value ratio reached 26 percent in 2004 and then jumped to 42 percent in 2010.

Lastly, and distressingly, financial wealth shows a drop-off between 2004 and 2010 for households aged 57-62, after staying steady in earlier periods. Median financial wealth net of non-mortgage debt dropped from $\$ 24,000$ in 2004 to $\$ 20,400$ in 2010, with the decline concentrated among mortgage-holders.

\section{Housing Distress in the HRS and PSID}

Now, we focus on detailed questions asked about housing distress in the 2008 HRS and the 2009 PSID. The HRS questions were asked of anyone with a mortgage in 2008 or anyone who ceased being a homeowner between 2006 and 2008, resulting in a sample of 2,847 households. The PSID questions were asked of 3,092 households. 


\subsection{Incidence of Housing Distress}

Table 3 shows summary statistics for the HRS sample of 2,847. ${ }^{12}$ In this group, 98 households (a weighted proportion of .030) were in arrears by two or more months in 2008 or had lost their home to foreclosure. Of these 98, 30 were actually in foreclosure, a weighted 0.75 percent foreclosure rate, and an additional 14 had lost their home to foreclosure. These rates of housing distress are well below the national averages of 4.8 percent in arrears and 3.3 percent in foreclosure. Of those who were not in arrears by two or more months, 120 anticipated that arrears were somewhat or very likely within the next six months - so an additional 4.7 percent reported themselves to be at risk of arrears. We do not know from this data whether a report of being likely to face arrears ultimately is borne out.

We first compare the housing characteristics of households that were in arrears in 2008 and those that were not, using weights to make the sample nationally representative. Households in arrears had higher mortgage payments as a percentage of income in 2006 (19 percent at the median, versus 10 percent for households not in arrears), bigger mortgages (\$108,000 at the median, versus $\$ 64,800)$, and lower house values $(\$ 162,000$ at the median, versus $\$ 216,000)$, leading to significantly lower home equity (\$44,280 at the median, versus $\$ 123,120$ for households not in arrears). Households in arrears were, however, less likely to hold a home equity loan (11 percent, versus 18 percent for those not in arrears) and had similar levels of non-housing debt $(\$ 7,416$ at the mean, versus $\$ 6,331)$. Lastly, households in arrears were much less likely to report that local housing conditions were good or excellent (14 percent, versus 42 percent for those not in arrears).

In comparing the characteristics of households that were in arrears and those that were not, it is apparent that the distressed group has worse socioeconomic characteristics. Among households in arrears, the financial respondent in the household was substantially less likely to have completed college (13 percent for those in arrears, versus 33 percent for those who were not) and more likely to be black (26 percent versus 8 percent) or Hispanic (13 percent versus 6 percent).

\footnotetext{
${ }^{12}$ We exclude from columns 2 and 3, 694 respondents who were not asked whether they anticipated arrears and 17 who either refused to answer or did not know.
} 
Households in arrears reported 35 percent lower income in 2006 than households not in arrears and 21 percent lower Social Security wealth expected at age 62, indicating lower permanent income. Yet, financial respondents of households in arrears were in fact slightly more likely to be working in 2006 (59 percent, versus 55 percent). In spite of the small sample of those in arrears, all of these differences between the samples are statistically significant, with the exception of working status; similar patterns are observed when comparing households who anticipated arrears and households who did not, among those not currently in arrears. Our regression analysis later will provide information about whether household income alone explains arrears, or whether factors like education and minority status play an independent role. Some differences are not statistically significant but go in the expected direction, as those in arrears were more likely to have been laid off in the last four years (20 percent, versus 11 percent), to divorce in the last four years (26 percent, versus 14 percent), to have a member experiencing fair or poor health two years ago (38 percent, versus 28 percent), to report a decline in health for the household head in the last two years (37 percent, versus 33 percent), and possess lower median financial wealth in 2006 (\$800, versus \$15,000).

Thus, all three conditions that lead to housing distress - declining home values, high mortgage payments, and interrupted income - appear among the HRS households in arrears or foreclosure in 2008, though not always significantly so. The sample size is too small to draw sharp conclusions about the role of each of these contributing factors, however.

We find similar patterns among older households in the 2009 PSID, as shown in Table 4. Rates of housing distress are higher among the older households than in the 2008 HRS, but they are lower than for the younger sample in the PSID. Among older households, with the head born in 1953 or before, 27 are currently in arrears (defined as two months or more) or foreclosure, amounting to 3.0 percent of the sample. In comparison, 4.2 percent of prime-age households are in arrears or foreclosure. 11.9 percent of the older sample anticipate arrears, and 15.4 percent of the younger sample do. The PSID also reveals that households experiencing housing distress are more likely to have a variable-rate mortgage, information that was not available in the HRS. Among older households, 20 percent of those not anticipating arrears have a variable-rate mortgage, and 42 percent of those in arrears (but not in foreclosure) do. By contrast, for prime- 
age households, the figures are 14 percent for those not anticipating arrears and 33 percent for those in arrears but not in foreclosure.

\subsection{Factors Associated with Housing Distress}

We analyze socioeconomic conditions that are associated with being at risk of arrears. To do so, we estimate weighted probit models using the HRS sample. In order to deal with the small sample size when analyzing factors contributing to housing distress, we will include the group that reports that arrears are somewhat or very likely within the next six months together with the group that is in arrears or has experienced foreclosure. As the group anticipating arrears has worse socioeconomic characteristics than the group not anticipating arrears, the subgroups considered together are relatively similar. This results in a sample of 178 households at risk of arrears and 1,748 not at risk. The number of households not at risk of arrears has shrunk from the 1,918 that appear in Table 3 to 1,748 because of missing data. The left-hand side variable in our probit model takes a value of one if the household is at risk of housing distress (already in arrears or foreclosure, or anticipating arrears within the next six months) and zero if not. The weights make the estimates nationally representative, and the weighted mean risk of housing distress in the sample is 9.4 percent.

The estimation results, reported in terms of estimated marginal effects, appear in Table 5. We find that higher income has a significant but small effect on the likelihood of being at risk of arrears. A 10 percent increase in log household income reduces this likelihood by about a tenth of a percentage point. ${ }^{13}$ Experiencing a layoff between 2004 and 2008 significantly raises the risk of being in arrears, by 6.2 percentage points. Experiencing a worsening of health between 2006 and 2008 also raises this risk significantly (at the 10 percent level), by 2.8 percentage points. Local housing conditions matter, as reporting that the local housing market is good significantly reduces the likelihood of arrears, by 4.8 percentage points. The average report of

\footnotetext{
${ }^{13}$ In another set of estimates, we tried including Social Security wealth computed at age 62 as a measure of permanent income not directly influenced by current work status. This reduces the sample size from 1926 to 1712, so we do not report the results here. Nevertheless, Social Security wealth has a negative effect that is statistically significant at the 10 percent level, and 2006 household income becomes marginally insignificant.
} 
local housing market conditions in one's MSA does not have a statistically significant effect that is independent of one's own report. ${ }^{14}$

Even after controlling for economic status, education and race affect the risk of arrears. Being a college graduate significantly reduces the risk of arrears by 4.5 percentage points, relative to having a high school degree. Being black raises the risk by 14.9 percentage points and being of another race raises it by 12 percentage points. Meanwhile, being Hispanic raises it by 5.0 percentage points. This is somewhat surprising and may reflect poor mortgage terms offered to ethnic minorities, as suggested anecdotally in some media reports.

We do not include other measures of household wealth as right-hand side variables, as these are correlated with housing wealth. We would be hesitant to attribute a causal interpretation to a variable like financial wealth, as households that are diligent in saving for retirement may also be careful about drawing down housing equity, so that it is not high financial wealth that causes households to avoid financial distress, but rather an innate sense of caution. We have some similar concerns about measures of housing obligations, which reflect housing markets (that can be viewed as exogenous) and housing choices (that may be endogenously determined with choosing not to keep up with current mortgage payments). Nevertheless, we have included the household's loan-to-value ratio from 2006 as an explanatory variable in the current set of results in order to capture the effects of exposure to housing market volatility, and it is statistically significant and positive. When the loan-to-value ratio rises by 10 percentage points, then the likelihood of being at risk of arrears rises by 0.77 percentage points. ${ }^{15}$

Stafford and Gouskova (2010) estimate a similar probit model using households of all ages in the PSID. They find a similar relationship between mortgage distress and education and ethnicity across ages, but in contrast to our analysis of HRS data, they find a significant and substantial

\footnotetext{
${ }^{14}$ This may also reflect a kind of justification bias, whereby people who formed more mistaken judgments about the future of housing markets blame a worse market for their mistakes.

${ }^{15}$ Few of the other coefficients are sensitive to including this variable.
} 
relationship between mortgage distress and debt service ratios. This likely reflects the much higher debt service ratios of the younger households included in the PSID. ${ }^{16}$

We then use our econometric model to forecast mortgage arrears and foreclosures among older households through 2012. Based on predicted changes in house values and employment, we project that the risk of mortgage arrears will increase to 3.4 percent in 2010 and 4.4 percent by 2012. ${ }^{17}$ These findings are consistent with the Mortgage Bankers Association delinquency rates which, in contrast to the American Life Panel data (Hurd and Rohwedder 2010), show no sign of having peaked.

\subsection{Housing Distress of Family Members}

The 2008 HRS asked all respondents whether they had family members (children or others) who were experiencing mortgage arrears and foreclosure. Thus, while older households have relatively low rates of housing distress, they may help other family members in trouble, and, in doing so, reduce their preparedness for retirement; their ability to offer such assistance may have risen as illiquid DB pensions have been replaced by more liquid DC accounts.

Table 6 reports the incidence of housing distress among family members of HRS respondents. Of 10,494 respondents, 6.7 percent reported having a family member who fell behind on his or her mortgage payments. Among the ones with a family member experiencing such trouble, 42 percent reported giving help to this family member, and 58 percent did not. Respondents with family members in distress had lower household income (\$46,656 at the median versus $\$ 52,294$ ) and lower financial wealth in 2006 (\$7,000 at the median versus $\$ 18,000)$ in comparison to respondents with no family members experiencing housing distress. However, within this group, those who gave help had considerably better finances than those who did not.

\footnotetext{
${ }^{16}$ The number of older households in the PSID is too small to replicate our HRS analysis or the Stafford-Gouskova model for older households alone.

${ }^{17}$ Our probit model estimates 2008 arrears as a function of 2006 loan to value ratios and layoffs 2004-2008. We use our model to forecast 2010 and 2012 arrears as a function of 2008 and 2010 loan to value ratios and 2006-2010 and 2008-2012 layoffs. This requires that we project house prices to 2010 and layoff rates to 2012 and impute layoffs 2008-2012 to households in our sample. We assume that layoffs peak in 2009 and decline to the 2006 level by 2012. We project each household's house price from 2008 to 2010, assuming that it tracks the relevant Metropolitan or Micropolitan house price index to the fourth quarter of 2009, and national house price movements thereafter.
} 
Table 7 reports the results of a probit model in which the dependent variable takes the value one if the respondent provided financial assistance to family members, zero otherwise. Younger, college educated individuals still in employment are more likely to provide assistance. However, the coefficients on variables measuring liquid financial wealth are not statistically significant. Thus, we cannot conclude from the evidence that older households are raiding their retirement nest eggs to assist family members in housing-related financial difficulty.

\section{Conclusions}

We find that households nearing retirement are more exposed to housing market volatility than in the recent past, and their retirement income may have to be stretched farther. Their mortgages have risen in value and their participation in the home equity loan market has risen. They gained housing wealth between 1992 and 2004, but these gains were almost entirely negated by 2010 . Nevertheless, the incidence of mortgage arrears and foreclosure among older households is relatively low, in comparison to the national average. Housing distress, when it does occur, is significantly related to layoffs and health shocks, as well as high loan-to-value ratios observed in 2006. Moreover, the incidence of housing distress is greater among ethnic minorities, even after controlling for income and education, possibly reflecting unfavorable mortgage terms. Our projections suggest that the risk of arrears will increase to 3.4 percent among older households in 2010, and 4.4 percent by 2012 .

The change in the nature of life cycle wealth portfolios may have important consequences as these households enter retirement. Housing wealth is illiquid, in comparison to financial wealth, and most households in retirement have traditionally shown great reluctance to downsize their houses in the absence of major shocks to the health status of household members. This may change in the near future as increasing demands on retirement income may require tapping into housing equity. This may either raise demand for reverse mortgages as a tool to smooth consumption in later years, or lead to more rapid consumption of pension wealth, which is growing increasingly liquid as annuities from DB plans have been replaced by lump-sum payouts from DB or DC plans. The changing portfolio of retirement wealth will bear further study as households enter retirement and begin to spend down their wealth. 


\section{References:}

AARP Public Policy Institute. 2008. “A First Look at Older Americans and the Mortgage Crisis," INSIGHT on the Issues.

Banks, James, Richard Blundell, Zoë Oldfield, and James P. Smith. 2007. "Housing Price Volatility and Downsizing in Later Life.” National Bureau of Economic Research Working Paper No. 13496.

Engelhardt, Gary, and Jonathan Gruber. 2006. "Social Security and the Evolution of Elderly Poverty,” in A.Auerbach, D.Card and J.Quigley, eds., Public Policy and the Income Distribution. New York: Russell Sage Foundation, p. 259-287.

Friedberg, Leora, and Michael Owyang. 2002. "Not Your Father's Pension Plan: The Rise of 401(k) and Other Defined Contribution Plans. Federal Reserve Bank of St. Louis Review, January/February 2002, Volume 84 (1), 23-34.

Friedberg, Leora, and Michael Owyang. 2005. "Explaining the Evolution of Pension Structure and Job Tenure.” Federal Reserve Bank of St. Louis Economics Working Paper \#2002-022D.

Hurd, Michael D., and Susan Rohwedder. 2010. "Effects of the Financial Crisis and Great Recession on American Households" National Bureau of Economic Research Working Paper No. 16,407 .

Stafford, Frank P., and Elena Gouskova. 2010. "Mortgage Contract Decisions and Mortgage Distress: Family and Financial Life-Cycle Factors" University of Michigan Retirement Research Center Working paper No. 2010-225.

Venti, Steven F., and David A. Wise. 2001. “Aging and Housing Equity: Another Look,” in D. Wise (ed), Perspectives on the Economics of Aging. Chicago: Chicago University Press, pp. 127-180. 
Table 1. Household wealth among cohorts ages 51-56 in 1992, 1998, and 2004

\begin{tabular}{|c|c|c|c|c|c|c|c|c|c|c|c|c|}
\hline & \multicolumn{4}{|c|}{ Ages 51-56 in 1992} & \multicolumn{4}{|c|}{ Ages 51-56 in 1998} & \multicolumn{4}{|c|}{ Ages 51-56 in 2004} \\
\hline & \multicolumn{2}{|c|}{ All homeowners } & \multicolumn{2}{|c|}{ With mortgage } & \multicolumn{2}{|c|}{ All homeowners } & \multicolumn{2}{|c|}{ With mortgage } & \multicolumn{2}{|c|}{ All homeowners } & \multicolumn{2}{|c|}{ With mortgage } \\
\hline & Mean & Median & Mean & Median & Mean & Median & Mean & Median & Mean & Median & Mean & Median \\
\hline & (1) & (2) & (3) & (4) & (5) & (6) & (7) & (8) & (9) & $(10)$ & $(11)$ & $(12)$ \\
\hline Value of primary residence & 190,417 & 140,400 & 207,082 & 156,000 & 197,262 & 144,000 & 217,002 & 180,000 & 283,658 & 203,000 & 314,371 & 232,000 \\
\hline Mortgage Debt & 49,952 & 15,600 & 73,248 & 45,240 & 61,374 & 28,800 & 91,253 & 69,120 & 80,596 & 46,400 & 112,589 & 90,480 \\
\hline Other loans & 9,380 & 0 & 13,745 & 0 & 5,465 & 0 & 8,125 & 0 & 9,355 & 0 & 13,069 & 0 \\
\hline Housing equity $^{1}$ & 131,086 & 93,600 & 120,080 & 88,920 & 130,422 & 93,600 & 117,624 & 86,400 & 193,707 & 116,000 & 188,714 & 113,680 \\
\hline Other debt & 6,270 & 0 & 6,991 & 0 & 7,004 & 0 & 8,272 & 0 & 6,472 & 0 & 7,560 & 0 \\
\hline 2nd home mortgage & 4,523 & 0 & 5,739 & 0 & 3,746 & 0 & 4,684 & 0 & 5,742 & 0 & 7,577 & 0 \\
\hline Total debt ${ }^{2}$ & 70,123 & 31,200 & 99,732 & 60,510 & 77,589 & 43,200 & 112,335 & 83,520 & 102,165 & 68,440 & 140,794 & 104,400 \\
\hline $\begin{array}{l}\text { Non-pension non-housing } \\
\text { financial wealth }^{3}\end{array}$ & 61,262 & 13,000 & 55,337 & 12,000 & 93,497 & 15,000 & 86,739 & 15,000 & 115,974 & 16,800 & 107,220 & 17,000 \\
\hline Total HH income & 92,555 & 72,696 & 100,550 & 80,184 & 114,351 & 85,127 & 123,223 & 93,623 & 120,563 & 82,824 & 131,846 & 92,800 \\
\hline Social Security wealth at age 62 & 137,867 & 139,932 & 142,559 & 145,704 & 121,259 & 124,212 & 126,360 & 128,964 & 149,973 & 148,944 & 156,251 & 155,324 \\
\hline DB wealth at age 62 & 317,462 & 183,207 & 328,515 & 196,278 & 386,388 & 306,398 & 398,784 & 323,414 & 240,752 & 187,927 & 248,198 & 190,634 \\
\hline $\begin{array}{l}\text { IRA balance+DC wealth in the } \\
\text { current job }\end{array}$ & 71,865 & 15,600 & 74,864 & 15,600 & 134,271 & 26,400 & 149,502 & 33,000 & 130,412 & 34,800 & 134,272 & 42,874 \\
\hline Has credit card debt & 0.41 & & 0.46 & & 0.40 & & 0.44 & & 0.43 & & 0.48 & \\
\hline Has home equity loan & 0.15 & & 0.22 & & 0.15 & & 0.22 & & 0.21 & & 0.29 & \\
\hline Has mortgage debt & 0.63 & & 0.92 & & 0.62 & & 0.92 & & 0.66 & & 0.91 & \\
\hline $\begin{array}{l}\% \text { of } \mathrm{HH} \text { with mortgage } \\
\text { payments exceeding } 30 \% \text { of } \\
\text { income }\end{array}$ & & 0.04 & & 0.07 & & 0.00 & & 0.01 & & 0.05 & & 0.09 \\
\hline Mortgage to home value ratio & 0.26 & 0.13 & 0.39 & 0.33 & 0.30 & 0.20 & 0.45 & 0.42 & 0.32 & 0.25 & 0.44 & 0.43 \\
\hline $\mathrm{N}$ of Obs. & \multicolumn{2}{|c|}{4,359} & \multicolumn{2}{|c|}{2,961} & \multicolumn{2}{|c|}{2,798} & \multicolumn{2}{|c|}{1,842} & \multicolumn{2}{|c|}{2,673} & \multicolumn{2}{|c|}{1,915} \\
\hline
\end{tabular}

Notes : Authors calculations using data from Health and Retirement Study. Estaimtes are weighted using household weights. All monetary values are in 2009 dollars.

${ }^{1}$ Housing equity equals the value of the primary residence minus of all mortgages and other loans.

${ }^{2}$ Total debt is the sum of all mortgages, other loans, 2nd home mortgages, and the value of other debt.

${ }^{3}$ This measure of financial wealth does not include IRA, business, or transportation wealth. 
Table 2. Household wealth among cohorts ages 57-62 in 1992, 1998, 2004, and 2010

\begin{tabular}{|c|c|c|c|c|c|c|c|c|c|c|c|c|c|c|c|c|}
\hline & \multicolumn{4}{|c|}{ Ages 57-62 in 1992} & \multicolumn{4}{|c|}{ Ages 57-62 in 1998} & \multicolumn{4}{|c|}{ Ages 57-62 in 2004} & \multicolumn{4}{|c|}{ Ages 57-62 in 2010} \\
\hline & \multicolumn{2}{|c|}{ All homeowners } & \multicolumn{2}{|c|}{ With mortgage } & \multicolumn{2}{|c|}{ All homeowners } & \multicolumn{2}{|c|}{ With mortgage } & \multicolumn{2}{|c|}{ All homeowners } & \multicolumn{2}{|c|}{ With mortgage } & \multicolumn{2}{|c|}{ All homeowners } & \multicolumn{2}{|c|}{ With mortgage } \\
\hline & Mean & Median & Mean & Median & Mean & Median & Mean & Median & Mean & Median & Mean & Median & Mean & Median & Mean & Median \\
\hline & $(1)$ & $(2)$ & (3) & (4) & (5) & (6) & $(7)$ & $(8)$ & (9) & $(10)$ & $(11)$ & $(12)$ & (13) & (14) & (15) & $(16)$ \\
\hline $\begin{array}{l}\text { Value of primary } \\
\text { residence }\end{array}$ & 175,617 & 132,600 & 200,187 & 148,200 & 220,786 & 144,000 & 263,530 & 180,000 & 268,417 & 175,160 & 298,535 & 207,640 & 213,407 & 153,360 & 235,666 & 176,364 \\
\hline Mortgage debt & 29,823 & 0 & 56,088 & 32,760 & 47,117 & 0 & 85,120 & 57,600 & 61,084 & 17,400 & 97,956 & 69,600 & 82,953 & 41,208 & 121,595 & 87,567 \\
\hline Other loans & 5,661 & 0 & 10,646 & 0 & 4,773 & 0 & 8,624 & 0 & 7,017 & 0 & 11,253 & 0 & 8,644 & 0 & 12,671 & 0 \\
\hline Housing equity $^{1}$ & 140,133 & 107,640 & 133,452 & 93,600 & 168,895 & 112,320 & 169,787 & 100,800 & 200,315 & 116,000 & 189,326 & 110,200 & 121,810 & 76,680 & 101,399 & 62,340 \\
\hline Other debt & 3,502 & 0 & 5,033 & 0 & 5,257 & 0 & 7,113 & 0 & 5,282 & 0 & 6,448 & 0 & 8,395 & 0 & 9,125 & 0 \\
\hline 2nd home mortgage & 3,616 & 0 & 4,148 & 0 & 4,093 & 0 & 6,183 & 0 & 4,058 & 0 & 5,365 & 0 & 6,090 & 0 & 8,149 & 0 \\
\hline Total debt ${ }^{2}$ & 42,602 & 11,700 & 75,916 & 46,800 & 61,240 & 20,880 & 107,040 & 73,440 & 77,442 & 38,280 & 121,022 & 87,000 & 106,082 & 60,782 & 151,540 & 103,020 \\
\hline $\begin{array}{l}\text { Non-pension non- } \\
\text { housing financial } \\
\text { wealth }^{3}\end{array}$ & 72,696 & 18,000 & 61,054 & 13,950 & 131,174 & 20,000 & 103,723 & 15,000 & 216,850 & 24,000 & 105,497 & 20,000 & 131,204 & 20,400 & 108,050 & 17,240 \\
\hline Total HH income & 76,941 & 59,592 & 87,137 & 68,640 & 102,536 & 68,256 & 116,734 & 80,150 & 99,476 & 70,296 & 107,001 & 80,091 & n.a & n.a & n.a & n.a \\
\hline $\begin{array}{l}\text { Social Security wealth } \\
\text { at age } 62\end{array}$ & 145,318 & 148,356 & 149,392 & 151,944 & 139,793 & 142,428 & 146,699 & 152,196 & 168,306 & 169,128 & 174,608 & 178,988 & 176,506 & 176,543 & 182,157 & 182,463 \\
\hline DB wealth at age 62 & 210,118 & 97,486 & 196,411 & 98,182 & 235,606 & 161,839 & 257,259 & 168,634 & 240,995 & 175,546 & 249,922 & 176,044 & 283,573 & 217,995 & 270,372 & 210,621 \\
\hline $\begin{array}{l}\text { IRA balance+ DC } \\
\text { wealth in the current } \\
\text { job }{ }^{4}\end{array}$ & 76,798 & 187,200 & 87,910 & 18,720 & 128,034 & 21,120 & 143,732 & 22,440 & 148,478 & 27,840 & 154,592 & 32,480 & 161,886 & 38,124 & 149,313 & 47,003 \\
\hline Has credit card debt & 0.35 & & 0.43 & & 0.32 & & 0.39 & & 0.37 & & 0.44 & & 0.44 & & 0.50 & \\
\hline Has home equity loan & 0.13 & & 0.24 & & 0.14 & & 0.25 & & 0.17 & & 0.27 & & 0.21 & & 0.30 & \\
\hline Has mortgage debt & 0.47 & & 0.88 & & 0.48 & & 0.87 & & 0.55 & & 0.88 & & 0.61 & & 0.89 & \\
\hline $\begin{array}{l}\% \text { of } \mathrm{HH} \text { with mortgage } \\
\text { pay ments exceeding } \\
30 \% \text { of income }\end{array}$ & & 0.00 & & 0.07 & & 0.00 & & 0.01 & & 0.03 & & 0.10 & & 0.06 & & 0.11 \\
\hline $\begin{array}{l}\text { Mortgage to home value } \\
\text { ratio }\end{array}$ & 0.17 & 0.00 & 0.32 & 0.25 & 0.22 & 0.00 & 0.39 & 0.35 & 0.26 & 0.10 & 0.42 & 0.38 & 0.42 & 0.33 & 0.57 & 0.52 \\
\hline N of Obs. & 3,5 & & 1,9 & & 3,8 & & 2,13 & & 2,53 & & 1,5 & & 2,3 & & 1,60 & 05 \\
\hline
\end{tabular}

Notes : Authors calculations using data from Health and Retirement Study. Estaimtes are weighted using household weights. All monetary values are in 2009 dollars.

${ }^{1}$ Housing equity equals the value of the primary residence minus all mortgages and other loans.

${ }^{2}$ Total debt is the sum of all mortgages, other loans, 2nd home mortgages, and other debt.

${ }^{3}$ This measure of financial wealth does not include IRA, business, or transportation wealth.

${ }^{4}$ The projected values of DC and IRA wealth are calcualted based on respondents report of account balances in 2008, their own contributions and employer contributions, and their investment allocation, as well as performance of the overall stock and bond markets during this period. 
Table 3: 2006 Characteristics of households with mortgages in 2006 by whether facing foreclosure in 2008

\begin{tabular}{|c|c|c|c|c|c|c|c|}
\hline \multirow{3}{*}{ Explanatory variables } & \multicolumn{3}{|c|}{ No past arrears } & \multicolumn{4}{|c|}{ Two or more months' arrears } \\
\hline & All & $\begin{array}{l}\text { Does not } \\
\text { anticipate } \\
\text { arrears }\end{array}$ & $\begin{array}{c}\text { Arrears } \\
\text { somewhat or } \\
\text { very likely in } \\
\text { the next } 6 \\
\text { months }^{1}\end{array}$ & $\mathrm{All}^{2}$ & $\begin{array}{l}\text { No } \\
\text { foreclosure }\end{array}$ & Foreclosure $^{3}$ & $\begin{array}{l}\text { Foreclosure } \\
\text { and lost } \\
\text { home }^{4}\end{array}$ \\
\hline & $(1)$ & $(2)$ & (3) & $(4)$ & $(5)$ & (6) & $(7)$ \\
\hline \multicolumn{8}{|l|}{ Race/ethnicity } \\
\hline White & 0.83 & 0.84 & $0.65^{\mathrm{a}}$ & $0.55^{a}$ & 0.55 & 0.56 & 0.73 \\
\hline Black & 0.08 & 0.07 & $0.17^{b}$ & $0.26^{a}$ & 0.28 & 0.22 & 0.27 \\
\hline Other & 0.03 & 0.03 & 0.07 & 0.06 & 0.06 & 0.08 & 0 \\
\hline Hispanic & 0.06 & 0.06 & $0.11^{\mathrm{c}}$ & $0.13^{c}$ & 0.12 & 0.14 & 0 \\
\hline \multicolumn{8}{|l|}{ Education } \\
\hline Less than High School & 0.11 & 0.07 & $0.17^{\mathrm{a}}$ & 0.18 & 0.17 & 0.20 & 0.11 \\
\hline High school & 0.30 & 0.28 & 0.34 & 0.38 & 0.42 & 0.28 & 0.30 \\
\hline Some College & 0.27 & 0.27 & 0.31 & 0.31 & 0.27 & 0.41 & 0.34 \\
\hline College graduate & 0.33 & 0.38 & $0.18^{\mathrm{a}}$ & $0.13^{a}$ & 0.14 & 0.11 & 0.25 \\
\hline Married in 2006 & 0.69 & 0.73 & 0.79 & 0.61 & 0.67 & 0.44 & 0.29 c \\
\hline Log of HH income in 2006 & 10.95 & 11.13 & $10.7^{\mathrm{a}}$ & $10.6^{b}$ & 10.8 & $10.1^{c}$ & $10.4^{\mathrm{c}}$ \\
\hline Age 60 or less in 2006 & 0.54 & 0.59 & $0.73^{a}$ & $0.71^{\mathrm{a}}$ & 0.72 & 0.68 & 0.82 \\
\hline Laid off between 2004-2008 & 0.11 & 0.10 & 0.24 & 0.20 & 0.21 & 0.15 & 0.19 \\
\hline Working in 2006 & 0.55 & 0.63 & 0.61 & 0.59 & 0.60 & 0.58 & 0.68 \\
\hline Has health insurance in 2006 & 0.96 & 0.97 & $0.91^{\mathrm{c}}$ & 0.94 & 0.96 & 0.89 & 0.76 \\
\hline Household member in fair/poor health in 2006 & 0.28 & 0.24 & $0.39 \mathrm{a}$ & 0.38 & 0.35 & 0.47 & 0.60 \\
\hline $\begin{array}{l}\text { HH report health change for worse between } \\
\text { 2006-2008 }\end{array}$ & 0.33 & 0.30 & $0.42^{\mathrm{b}}$ & 0.37 & 0.38 & 0.35 & 0.61 \\
\hline $\begin{array}{l}\text { Health expenditures above 75th percentile in } \\
2006\end{array}$ & 0.33 & 0.35 & 0.30 & 0.40 & 0.40 & 0.40 & 0.60 \\
\hline $\begin{array}{l}\text { Reports local housing market as good or } \\
\text { above in } 2006\end{array}$ & 0.42 & 0.44 & $0.27^{\mathrm{a}}$ & $0.14^{\mathrm{a}}$ & 0.16 & 0.08 & $0.04^{\mathrm{c}}$ \\
\hline $\begin{array}{l}\text { \% of people in same MSA in } 2006 \text { rating local } \\
\text { housing market as good or excellent }\end{array}$ & 0.39 & 0.40 & $0.34^{\mathrm{b}}$ & 0.34 & 0.35 & 0.33 & 0.39 \\
\hline Loan to value ratio in 2006 & 0.34 & 0.39 & $0.50^{\mathrm{b}}$ & $0.62^{a}$ & 0.65 & 0.51 & 0.60 \\
\hline \multicolumn{8}{|l|}{ Variables not included in the probit model } \\
\hline $\begin{array}{l}\text { Median mortgage payments as \% of } \mathrm{HH} \\
\text { income in } 2006\end{array}$ & 0.10 & 0.12 & 0.17 & 0.19 & 0.15 & 0.28 & 0.36 \\
\hline Median mortgage debt in 2006 & 64,800 & 86,400 & 91,800 & 108,000 & 91,800 & 140,400 & 131,562 \\
\hline Median house value in 2006 & 216,000 & 237,600 & 183,600 & 162,000 & 135,819 & 253,800 & 118,800 \\
\hline Median housing equity in 2006 & 123,120 & 129,600 & 91,800 & 44,280 & 43,200 & 72,036 & 64,800 \\
\hline \% with home equity loan in 2006 & 0.18 & 0.20 & 0.18 & 0.11 & 0.05 & $0.31^{c}$ & $0.60^{\mathrm{a}}$ \\
\hline $\begin{array}{l}\text { Mean Value of other debt (credit card, } \\
\text { medical debts etc) in } 2006\end{array}$ & 6,331 & 6,888 & 9,872 & 7416 & 7,604 & 6,841 & 14,497 c \\
\hline Mean Social Security wealth at age 62 & 156,518 & 161,034 & 138,995 a & 124,249 & 123,622 & 126,198 & 128,224 \\
\hline Divorced between 2004-2008 & 0.14 & 0.14 & 0.12 & $0.26^{c}$ & 0.24 & 0.32 & 0.53 \\
\hline $\begin{array}{l}\text { Median HH non-pension non-housing } \\
\text { financial wealth in } 2006^{5} \\
\end{array}$ & 15,000 & 15,000 & 3,800 & 800 & 1,000 & 500 & 3 \\
\hline $\mathrm{N}$ & 2749 & 1918 & 120 & 98 & 68 & 30 & 14 \\
\hline \multicolumn{8}{|c|}{ Notes : Authors calculations using data from Health and Retirement Study. Estaimtes are weighted using household weights. All monetary values are in 2009 dollars. } \\
\hline \multicolumn{8}{|c|}{${ }^{1}$ Significance test between column (1) and (4) are reported in this column } \\
\hline \multicolumn{8}{|c|}{${ }^{2}$ Significance test between column (2) and (3) are reported in this column } \\
\hline \multicolumn{8}{|c|}{${ }^{3}$ Significance test between column (5) and (6) are reported in this colum } \\
\hline \multicolumn{8}{|c|}{${ }^{4}$ Significance test between column (5) and (7) are reported in this colum } \\
\hline \multicolumn{8}{|c|}{${ }^{5}$ This measure of financial wealth does not include IRA, business, or transportation wealth. } \\
\hline a, b and ${ }^{c}$ denote significance at 1,5 , and 10 percent le & & & & & & & \\
\hline
\end{tabular}


Table 4: 2006 Characteristics of homeowner households in 2007 in PSID by whether anticipating arrears or facing foreclosure in 2009

\begin{tabular}{|c|c|c|c|c|c|c|c|c|c|c|c|c|}
\hline \multirow{4}{*}{ Explanatory variables } & \multicolumn{4}{|c|}{ Everyone } & \multicolumn{4}{|c|}{ HH head born in 1953 or earlier } & \multicolumn{4}{|c|}{ PH head born 1954 or later } \\
\hline & \multicolumn{2}{|c|}{ Not in arreas } & \multicolumn{2}{|c|}{ Currently in arreas } & \multicolumn{2}{|c|}{ Not in arreas } & \multicolumn{2}{|c|}{ Currently in arreas } & \multicolumn{2}{|c|}{ Not in arreas } & \multicolumn{2}{|c|}{ Currently in arreas } \\
\hline & $\begin{array}{c}\text { Anticipate } \\
\text { arreas }\end{array}$ & $\begin{array}{c}\text { Does not } \\
\text { anticipate } \\
\text { arrears }\end{array}$ & $\begin{array}{c}\text { Into } \\
\text { foreclosure }\end{array}$ & $\begin{array}{c}\text { Not in } \\
\text { foreclosure }\end{array}$ & $\begin{array}{c}\text { Anticipate } \\
\text { arreas }\end{array}$ & $\begin{array}{c}\text { Does not } \\
\text { anticipate } \\
\text { arrears }\end{array}$ & $\begin{array}{c}\text { Into } \\
\text { foreclosure }\end{array}$ & $\begin{array}{c}\text { Not in } \\
\text { foreclosure }\end{array}$ & $\begin{array}{c}\text { Anticipate } \\
\text { arreas }^{1}\end{array}$ & $\begin{array}{c}\text { Does not } \\
\text { anticipate } \\
\text { arrears }^{2}\end{array}$ & $\begin{array}{c}\text { Into } \\
\text { foreclosure }^{3}\end{array}$ & $\begin{array}{c}\text { Not in } \\
\text { foreclosure }^{4}\end{array}$ \\
\hline & $(1)$ & $(2)$ & (3) & (4) & (5) & (6) & $(7)$ & $(8)$ & (9) & $(10)$ & $(11)$ & $(12)$ \\
\hline \multicolumn{13}{|l|}{ Race/ethnicity } \\
\hline White & 0.57 & 0.84 & 0.67 & 0.49 & 0.54 & 0.86 & 0.82 & 0.66 & 0.58 & 0.83 & 0.60 & 0.43 \\
\hline Black & 0.12 & 0.07 & 0.19 & 0.20 & 0.17 & 0.08 & 0.08 & 0.15 & 0.10 & 0.07 & $0.24^{\mathrm{a}}$ & 0.22 \\
\hline Other & 0.05 & 0.03 & 0.00 & 0.04 & 0.07 & 0.04 & 0.00 & 0.01 & 0.04 & 0.03 & 0.00 & 0.05 \\
\hline Hispanic & 0.26 & 0.05 & 0.14 & 0.27 & 0.22 & 0.03 & 0.11 & 0.17 & 0.28 & $0.06^{\mathrm{a}}$ & 0.16 & 0.31 \\
\hline \multicolumn{13}{|l|}{ Education } \\
\hline Less than High School & 0.22 & 0.08 & 0.21 & 0.22 & 0.26 & 0.10 & 0.37 & 0.09 & 0.21 & $0.06^{\mathrm{a}}$ & 0.14 & 0.26 \\
\hline High school & 0.34 & 0.26 & 0.40 & 0.42 & 0.35 & 0.26 & 0.35 & 0.26 & 0.34 & 0.26 & 0.42 & $0.47^{b}$ \\
\hline Some College & 0.23 & 0.26 & 0.32 & 0.16 & 0.18 & 0.23 & 0.25 & 0.34 & 0.25 & $0.28 \mathrm{~b}$ & 0.35 & $0.10^{b}$ \\
\hline College graduate & 0.20 & 0.40 & 0.07 & 0.20 & 0.20 & 0.40 & 0.03 & 0.30 & 0.20 & 0.40 & 0.10 & 0.17 \\
\hline Married in 2007 & 0.67 & 0.71 & 0.57 & 0.62 & 0.66 & 0.67 & 0.62 & 0.72 & 0.67 & $0.73^{b}$ & 0.54 & 0.58 \\
\hline $\begin{array}{l}\text { Mean of Log of HH income } \\
2007\end{array}$ & 10.99 & 11.35 & 10.33 & 11.03 & 10.95 & 11.23 & 8.81 & 11.0 & 11.0 & $11.4^{\mathrm{a}}$ & 11.1 & 11.1 \\
\hline Median & 11.08 & 11.38 & 11.01 & 10.94 & 11.05 & 11.24 & 10.17 & 10.8 & 11.1 & 11.4 & 11.1 & 10.9 \\
\hline Working in 2007 & 0.88 & 0.84 & 0.58 & 0.87 & 0.81 & 0.66 & 0.28 & 0.87 & $0.91 \mathrm{~b}$ & $0.95^{\mathrm{a}}$ & $0.73^{c}$ & 0.86 \\
\hline Laid off between 2003-07 & 0.12 & 0.06 & 0.07 & 0.13 & 0.15 & 0.04 & 0.18 & 0.01 & 0.11 & $0.07^{\mathrm{a}}$ & 0.02 & $0.17^{\mathrm{b}}$ \\
\hline Has health insurance 2007 & 0.94 & 0.98 & 0.92 & 0.90 & 0.93 & 0.98 & 1.00 & 0.93 & 0.94 & 0.97 & 0.89 & 0.90 \\
\hline $\begin{array}{l}\text { Household member in fair/poor } \\
\text { health } 2007\end{array}$ & 0.24 & 0.14 & 0.29 & 0.23 & 0.41 & 0.22 & 0.51 & 0.35 & $0.17^{\mathrm{a}}$ & $0.09^{\mathrm{a}}$ & 0.18 & 0.20 \\
\hline $\begin{array}{l}\text { HH report health change for } \\
\text { worse between 2005-07 }\end{array}$ & 0.28 & 0.30 & 0.25 & 0.23 & 0.35 & 0.31 & 0.15 & 0.37 & 0.26 & 0.29 & 0.30 & 0.19 \\
\hline $\begin{array}{l}\text { Health expenditures above } \\
\text { 75th percentile in } 2007\end{array}$ & 0.31 & 0.39 & 0.28 & 0.26 & 0.45 & 0.45 & 0.46 & 0.38 & $0.27^{b}$ & $0.36^{\mathrm{a}}$ & 0.22 & 0.22 \\
\hline Mean Loan to value ratio 2007 & 0.57 & 0.50 & 0.67 & 0.75 & 0.51 & 0.39 & 0.65 & 0.70 & $0.59^{c}$ & $0.57^{\mathrm{a}}$ & 0.68 & 0.77 \\
\hline Median & 0.62 & 0.50 & 0.79 & 0.80 & 0.51 & 0.36 & 0.80 & 0.72 & 0.67 & 0.59 & 0.74 & 0.80 \\
\hline $\begin{array}{l}\text { Age of head of household } \\
2007\end{array}$ & 46.7 & 48.8 & 48.8 & 44.3 & 61.2 & 62.4 & 61.6 & 57.9 & $41.1^{\mathrm{a}}$ & $40.5^{\mathrm{a}}$ & $42.6 \mathrm{a}$ & $40.0^{\mathrm{a}}$ \\
\hline Has children under age 18 & 0.54 & 0.39 & 0.54 & 0.48 & 0.30 & 0.08 & 0.12 & 0.25 & $0.63^{\mathrm{a}}$ & $0.58^{a}$ & $0.75^{\mathrm{a}}$ & $0.55^{\mathrm{c}}$ \\
\hline Divorced between 2003-07 & 0.04 & 0.04 & 0.06 & 0.06 & 0.02 & 0.03 & 0.00 & 0.00 & 0.05 & 0.04 & 0.09 & 0.07 \\
\hline
\end{tabular}




\section{Table 4 (cont.)}

\begin{tabular}{|c|c|c|c|c|c|c|c|c|c|c|c|c|}
\hline & $(1)$ & (2) & (3) & (4) & (5) & (6) & $(7)$ & $\overline{(8)}$ & (9) & $(10)$ & $(11)$ & (12) \\
\hline $\begin{array}{l}\text { Mean health expenditure } \\
2007\end{array}$ & 5,978 & 7,268 & 5,012 & 5,840 & 8,952 & 8,611 & 4,492 & 8,122 & 5,059 b & $6,506^{\mathrm{a}}$ & 5,190 & 5,099 \\
\hline Median & $3,842^{\prime}$ & $5,150^{\prime}$ & 3,523 & 3,811 & $5,871^{\prime}$ & 5,871 & $52^{\prime}$ & 6,386 & 2,987 & 4,532 & 3523 & 3,381 \\
\hline Mean house value 2007 & 255,492 & 309,071 & 255,219 & 304,254 & 259,416 & 329,346 & 205,404 & 262,757 & 253,997 & $296,809^{b}$ & 279,816 & 318,130 \\
\hline Median & 195,000 & 225,000 & 230,000 & 200,000 & 200,000 & 240,000 & 250,000 & 150,000 & 190,000 & 223,000 & 230,000 & 200,000 \\
\hline Mean mortgage debt 2007 & 132,500 & 137,159 & 170,562 & 216,103 & 125,101 & $112,289^{r}$ & 124,586 & 149,141 & 135,192 & $152,421^{\mathrm{a}}$ & 192,820 & 236,937 \\
\hline Median & 105,000 & 103,000 & 146,000 & 120,000 & 84,000 & 72,000 & 140,000 & 100,000 & 110,000 & 120,000 & 160,000 & 131,000 \\
\hline Mean total debt 2007 & 145,104 & 154,775 & 190,215 & 238,516 & 138,568 & 130,421 & 145,828 & 170,750 & 147,497 & $169,688^{a}$ & 211,703 & 259,600 \\
\hline Median & 114,433 & 118,450 & 179,220 & 133,900 & 92,700 & 82,400 & 149,350 & 104030 & 118,450 & 134,930 & 179,220 & 134,930 \\
\hline Mean Total HH income 2007 & 77,887 & 113,651 & 61,957 & 74,743 & 74,559 & 105,076 & 39,773 & 71,311 & 79,140 & $118,909^{b}$ & 72,696 & 75,811 \\
\hline Median & 64,660 & 87,496 & 60,632 & 56,710 & 63,240 & 76,320 & 26,089 & 48,866 & 65,296 & 92,375 & 68,529 & 56,710 \\
\hline $\begin{array}{l}\text { Mean mortgage payments } \\
\text { as \% of HH income } 2007\end{array}$ & 0.23 & 0.18 & 0.31 & 0.35 & 0.24 & 0.20 & 0.42 & 0.58 & 0.23 & 0.17 & $0.26^{b}$ & 0.28 \\
\hline Median & 0.18 & 0.13 & 0.22 & 0.21 & 0.17 & 0.12 & 0.42 & 0.16 & 0.18 & 0.14 & 0.21 & 0.21 \\
\hline $\begin{array}{l}\text { \% with home equity loan } \\
2007\end{array}$ & 0.13 & 0.18 & 0.17 & 0.13 & 0.16 & 0.21 & 0.17 & 0.09 & 0.12 & $0.16^{\mathrm{a}}$ & 0.18 & 0.14 \\
\hline \% Has credit card debt 2007 & 0.63 & 0.61 & 0.75 & 0.78 & 0.55 & 0.52 & 0.94 & 0.96 & 0.66 & $0.67^{\mathrm{a}}$ & $0.66^{\mathrm{b}}$ & $0.73^{\mathrm{a}}$ \\
\hline Mean DC + IRA wealth & 21,348 & 83,516 & 2,549 & 17,030 & 36,145 & 119,928 & 3,340 & 13,418 & $15,693^{b}$ & $61,314^{\mathrm{a}}$ & 2,166 & 18,154 \\
\hline Median & 0 & 7,210 & 0 & 0 & 0 & 15,450 & 0 & 0 & 0 & 4,944 & 0 & 0 \\
\hline Mean Housing equity 2007 & 113,994 & 171,070 & 79,748 & 89,236 & 126,183 & 216,332 & 72,318 & 117,025 & 109,395 & $143,491^{\mathrm{a}}$ & 83,344 & 80,590 \\
\hline Median & 72,100 & 103,000 & 61,800 & 51,500 & 94,760 & 149,350 & 51,500 & 51,500 & 58,710 & 78,280 & 61,800 & 51,500 \\
\hline Mean financial assets 2007 & $30,717^{7}$ & $92,211^{7}$ & $87,207^{\prime}$ & 37,454 & 37,072 & 123,914 & 253,080 & 15,841 & 28,311 & $72,887^{a}$ & 6,906 & 44,179 \\
\hline Median & $3,090^{\top}$ & 14,420 & 1,030 & 412 & $3,090^{\prime}$ & 21,630 & $515^{\prime}$ & 412 & 3,090 & 11,330 & 1,288 & 927 \\
\hline Refinanced & 0.54 & 0.55 & 0.58 & 0.67 & 0.58 & 0.62 & 0.79 & 0.89 & 0.53 & $0.51^{\mathrm{a}}$ & 0.48 & $0.60^{\mathrm{a}}$ \\
\hline Interest rate is variable & 0.17 & 0.16 & 0.67 & 0.36 & 0.20 & 0.20 & 0.97 & 0.42 & 0.16 & $0.14^{\mathrm{a}}$ & $0.52^{\mathrm{a}}$ & 0.33 \\
\hline $\mathrm{N}$ & 446 & 2,522 & 35 & 83 & 107 & 762 & 9 & 18 & 338 & 1,759 & 26 & 65 \\
\hline \multicolumn{13}{|c|}{$\begin{array}{l}\text { Notes : Data are from PSID. Estimates are weighted using family weights. Unit of analy sis is family, and charactersitics are for the head of the family unless otherwise noted. All monetary values } \\
\text { are in } 2009 \text { dollars. }\end{array}$} \\
\hline \multicolumn{13}{|c|}{${ }^{1}$ Significance test of the difference in estimates in columns (5) and (9) are reported in this column } \\
\hline \multicolumn{13}{|c|}{${ }^{2}$ Significance test of the difference in estiamtes in columns (6) and (9) are reported in this colum } \\
\hline \multicolumn{13}{|c|}{${ }^{3}$ Significance test of the difference in estimates in columns (7) and (10) are reported in this column } \\
\hline \multicolumn{13}{|c|}{${ }^{4}$ Significance test of the difference in estimates in columns (8) and (12) are reported in this column } \\
\hline${ }^{\mathrm{b}}$ and ${ }^{\mathrm{c}}$ denote significance at 1 & , 5, and 10 perc & level. & & & & & & & & & & \\
\hline
\end{tabular}


Table 5. Probit marginal effects--risk of arrears or foreclosure

\begin{tabular}{|c|c|c|}
\hline Independent variables & $\begin{array}{c}\text { Marginal } \\
\text { effect }\end{array}$ & Std. Err. \\
\hline \multicolumn{3}{|l|}{ Race/ethincity } \\
\hline \multicolumn{3}{|l|}{ Non Hispanic White (omitted) } \\
\hline Non Hispanic black & $0.149^{\mathrm{a}}$ & 0.038 \\
\hline Non Hispanic other & $0.120^{\mathrm{b}}$ & 0.068 \\
\hline Hispanic & $0.050^{\mathrm{b}}$ & 0.028 \\
\hline \multicolumn{3}{|l|}{ Education } \\
\hline Less than high school & 0.010 & 0.024 \\
\hline \multicolumn{3}{|l|}{ High school graduate (omitted) } \\
\hline Some college & -0.010 & 0.015 \\
\hline College Graduate & $-0.045^{b}$ & 0.016 \\
\hline Married in 2006 & 0.013 & 0.014 \\
\hline Age less than 60 in 2006 & $0.041^{\mathrm{a}}$ & 0.015 \\
\hline Working in 2006 & -0.003 & 0.016 \\
\hline Has health insurance in 2006 & -0.048 & 0.039 \\
\hline HH in Fair/poor health in 2006 & 0.018 & 0.017 \\
\hline HH health change for worse between 2006-2008 & $0.028^{c}$ & 0.016 \\
\hline Laid-off between 2004-2008 & $0.062^{\mathrm{a}}$ & 0.026 \\
\hline Health expenditures in 2006 above the $75^{\text {th }}$ percentile & 0.001 & 0.014 \\
\hline Report local housing market as good/verygood/excellent & $-0.048^{a}$ & 0.015 \\
\hline Mean assessment of local market by people in the same MSA & -0.043 & 0.036 \\
\hline Log of household income in 2006 & $-0.009^{b}$ & 0.004 \\
\hline Loan to value ratio in 2006 & $0.077^{a}$ & 0.020 \\
\hline N of Obs. & \multicolumn{2}{|c|}{1926} \\
\hline Log likelihood & \multicolumn{2}{|c|}{-504.081} \\
\hline Pseudo R2 & \multicolumn{2}{|c|}{0.157} \\
\hline obs. P & \multicolumn{2}{|c|}{0.093} \\
\hline pred. P (at x-bar) & \multicolumn{2}{|c|}{0.064} \\
\hline $\begin{array}{l}\text { Notes : Authors calculations using data from Health and Retirement Study. Es } \\
\text { weights. All monetary values are in } 2009 \text { dollars. }\end{array}$ & ntes are weig & Ising househo \\
\hline
\end{tabular}


Table 6. Respondent's family (not including the respondent) fell behind in mortgage payment

\begin{tabular}{|c|c|c|c|c|c|c|c|c|c|c|}
\hline \multirow{4}{*}{ Explanatory variables } & \multirow{2}{*}{\multicolumn{2}{|c|}{ All }} & \multirow{2}{*}{\multicolumn{2}{|c|}{$\begin{array}{c}\text { Family did not } \\
\text { fall behind }\end{array}$}} & \multicolumn{6}{|c|}{ Family fell behind } \\
\hline & & & & & \multicolumn{2}{|l|}{$\mathrm{All}^{1}$} & \multicolumn{2}{|c|}{ R gave help } & \multicolumn{2}{|c|}{ R did not give help ${ }^{2}$} \\
\hline & Mean & Median & Mean & Median & Mean I & Median & Mean & Median & Mean & Median \\
\hline & $(1)$ & $(2)$ & (3) & (4) & (5) & (6) & $(7)$ & $(8)$ & (9) & $(10)$ \\
\hline \multicolumn{11}{|l|}{ Race/ethnicity } \\
\hline White & 0.82 & & 0.82 & & $0.77^{\mathrm{a}}$ & & 0.81 & & $0.74^{\mathrm{c}}$ & \\
\hline Black & 0.07 & & 0.07 & & 0.09 & & 0.08 & & 0.09 & \\
\hline Other & 0.03 & & 0.03 & & 0.03 & & 0.03 & & 0.03 & \\
\hline Hispanic & 0.08 & & 0.08 & & $0.11^{\mathrm{b}}$ & & 0.08 & & $0.14^{\mathrm{b}}$ & \\
\hline \multicolumn{11}{|l|}{ Education } \\
\hline Less than high school & 0.16 & & 0.16 & & 0.18 & & 0.13 & & $0.22^{\mathrm{a}}$ & \\
\hline High school & 0.33 & & 0.33 & & $0.39^{\mathrm{a}}$ & & 0.37 & & 0.42 & \\
\hline Some college & 0.25 & & 0.25 & & 0.26 & & 0.27 & & 0.24 & \\
\hline College graduate & 0.26 & & 0.27 & & $0.17^{\mathrm{a}}$ & & 0.23 & & $0.12^{\mathrm{a}}$ & \\
\hline Married in 2006 & 0.72 & & 0.72 & & 0.74 & & 0.79 & & $0.70^{\mathrm{b}}$ & \\
\hline Age 60 or less in 2006 & 0.44 & & 0.44 & & $0.51^{\mathrm{a}}$ & & 0.47 & & 0.54 & \\
\hline Working in 2006 & 0.43 & & 0.43 & & 0.45 & & 0.51 & & $0.38^{\mathrm{a}}$ & \\
\hline Household member in fair/poor health 06 & 0.34 & & 0.33 & & 0.37 & & 0.32 & & $0.41^{\mathrm{c}}$ & \\
\hline Has children under age 18 & 0.07 & & 0.07 & & $0.10^{\mathrm{c}}$ & & 0.12 & & 0.09 & \\
\hline Value of primary residence & 271,533 & 162,000 & 275,375 & 162,000 & $216,626^{a}$ & 162,000 & 229,021 & 167,400 & 208,395 & 140,400 \\
\hline Total mortgage debt & 50,965 & 0 & 50,563 & 0 & 56,717 & 0 & 52,968 & 0 & 59,488 & 0 \\
\hline Total HH income & 85,941 & 52,056 & 87,300 & 52,294 & $66,521^{a}$ & 46,656 & 80,687 & 58,320 & $55,266^{a}$ & 34,733 \\
\hline Total debt ${ }^{3}$ & 66,591 & 6,480 & 66,134 & 5,400 & 73,123 & 27,000 & 72,071 & 38,880 & 73,747 & 21,600 \\
\hline Net value of financial wealth ${ }^{4}$ & 185,678 & 16,000 & 193,118 & 18,000 & $79,365^{a}$ & 7,000 & 84,634 & 15,000 & 74,532 & 3,000 \\
\hline Housing equity ${ }^{5}$ & 214,584 & 108,000 & 218,802 & 112,320 & $154,322^{a}$ & 97,200 & 169,313 & 108,000 & 144,197 & 70,200 \\
\hline Social Security wealth at age 62 & 144,009 & 143,956 & 144,520 & 144,304 & $137,448^{b}$ & 137,904 & 147,685 & 146,276 & $128,393^{a}$ & 122,288 \\
\hline DB wealth at age 62 & 280,231 & 185,443 & 281,173 & 190,278 & 267,286 & 138,579 & 327,994 & 146,956 & $201,091^{b}$ & 116,014 \\
\hline Has DB plan & 0.26 & & 0.26 & & 0.27 & & 0.32 & & $0.23^{\mathrm{b}}$ & \\
\hline Has DC plan & 0.49 & & 0.48 & & $0.55^{\mathrm{a}}$ & & 0.60 & & $0.51^{\mathrm{c}}$ & \\
\hline Has IRA & 0.58 & & 0.59 & & $0.51^{\mathrm{a}}$ & & 0.60 & & $0.44^{\mathrm{a}}$ & \\
\hline $\mathrm{N}$ & 10,4 & 494 & 9,7 & 791 & 703 & & & 96 & 399 & \\
\hline \multicolumn{11}{|c|}{ Notes : Data are from Heath and Retirement Study. Estimates are weighted using household weights. All monetary values are in 2009 dollars. } \\
\hline \multicolumn{11}{|c|}{${ }^{1}$ Significance test of the difference in estimates in columns (3) and (5) are reported in this column } \\
\hline \multicolumn{11}{|c|}{${ }^{2}$ Significance test of the difference in estiamtes in columns (7) and (9) are reported in this colum } \\
\hline \multicolumn{11}{|c|}{${ }^{3}$ Total debt is the sum of all mortgages, other loans, 2nd home mortgages, and other debt. } \\
\hline \multicolumn{11}{|c|}{${ }^{4}$ This measure of financial wealth does not include IRA, business, or transportation wealth. } \\
\hline \multicolumn{11}{|c|}{${ }^{5}$ Housing equity equals the value of the primary residence minus all mortgages and other loans. } \\
\hline $\mathrm{a}, \mathrm{b}$ and ${ }^{\mathrm{c}}$ denote significance at 1,5 , and 10 percent & level. & & & & & & & & & \\
\hline
\end{tabular}




\section{Table 7. Probit marginal effects of the probability of giving help to family member (not including the respondent) that fell behind in mortgage}

payment

\begin{tabular}{|c|c|c|}
\hline \multirow[t]{2}{*}{ Explanatory variables } & \multirow{2}{*}{$\begin{array}{c}\text { Marginal effects } \\
\text { (1) }\end{array}$} & \multirow{2}{*}{$\begin{array}{l}\text { Std. Err. } \\
(2) \\
\end{array}$} \\
\hline & & \\
\hline \multicolumn{3}{|l|}{ Race/ethnicity } \\
\hline \multicolumn{3}{|l|}{ Non Hispanic White (omitted) } \\
\hline Non Hispanic Black & -0.003 & 0.076 \\
\hline Non Hispanic Other & -0.095 & 0.129 \\
\hline Hispanic & -0.058 & 0.083 \\
\hline \multicolumn{3}{|l|}{ Education } \\
\hline Less than High School & -0.035 & 0.072 \\
\hline \multicolumn{3}{|l|}{ High school (omitted) } \\
\hline Some College & 0.045 & 0.065 \\
\hline College graduate & $0.151^{b}$ & 0.074 \\
\hline Married in 2006 & 0.066 & 0.061 \\
\hline Age 60 or less in 2006 & $-0.178^{\mathrm{a}}$ & 0.058 \\
\hline Working in 2006 & 0.138 & 0.061 \\
\hline Household member in fair/poor health in 2006 & -0.005 & 0.056 \\
\hline Has DB plan & 0.042 & 0.078 \\
\hline Has DC plan & -0.024 & 0.056 \\
\hline Has IRA & 0.050 & 0.071 \\
\hline $\log ($ Total HH income) & 0.016 & 0.022 \\
\hline $\log (\mathrm{db}$ dc ira wealth) & 0.004 & 0.007 \\
\hline $\mathrm{N}$ of Obs. & \multicolumn{2}{|c|}{621} \\
\hline Log likelihood & \multicolumn{2}{|c|}{-399.532} \\
\hline Pseudo R2 & \multicolumn{2}{|c|}{0.065} \\
\hline obs. P & \multicolumn{2}{|c|}{0.449} \\
\hline pred. P (at x-bar) & \multicolumn{2}{|c|}{0.444} \\
\hline
\end{tabular}

Notes : Authors calculations using data from Health and Retirement Study. Estaimtes are weighted using household weights. All monetary values are in 2009 dollars.

${ }^{a}$ and ${ }^{\mathrm{b}}$ denote significance at 1 and 5 percent level. 


\section{RECENT WORKING PAPERS FROM THE CENTER FOR RETIREMENT RESEARCH AT BOSTON COLLEGE}

Children and Household Utility: Evidence from Kids Flying the Coop

Norma B. Coe and Anthony Webb, November 2010

Overview of the CRR 2009 Retirement Survey

Alicia H. Munnell, Norma B. Coe, Kelly Haverstick, and Steven A. Sass, October 2010

State Wage-Payment Laws, the Pension Protection Act of 2006, and 401(k) Saving Behavior

Gary Engelhardt, October 2010

Asset Cycles and the Retirement Decisions of Older Workers

Jan Ondrich, October 2010

Price Deflators, the Trust Fund Forecast, and Social Security Solvency

Barry Bosworth, October 2010

The Impact of a DROP Program on the Age of Retirement and Employer Pension Costs Samson Alva, Norma B. Coe, and Anthony Webb, September 2010

Housing Consumption in Late Life: The Role of Income, Health Shocks, and Marital Shocks

Douglas A. Wolf and Janet M. Wilmoth, September 2010

Adjusting Social Security for Increasing Life Expectancy: Effects on Progressivity

Courtney Monk, John A. Turner, and Natalia A. Zhivan, August 2010

Work and Retirement Patterns for the G.I. Generation, Silent Generation, and Early Boomers: Thirty Years of Change

Richard W. Johnson, Barbara A. Butrica, and Corina Mommaerts, July 2010

Spousal Health Shocks and the Timing of the Retirement Decision in the Face of ForwardLooking Financial Incentives

Courtney Harold Van Houtven and Norma B. Coe, June 2010

Incorporating Employee Heterogenity Into Default Rules for Retirement Plan Selection Gopi Shah Godi and Colleen Flaherty Manchester, May 2010

Accurately Measuring Health Over the Life Course

Fabian Lange and Doug McKee, May 2010

Getting to the Top of Mind: How Reminders Increase Saving

Dean Karlan, Margaret McConnell, Sendhil Mullainathan, and Jonathan Zinman, April 2010

All working papers are available on the Center for Retirement Research website (http://crr.bc.edu) and can be requested by e-mail (crr@bc.edu) or phone (617-552-1762). 